NATALIA DVORNYICSENKO

THE SPECIFIC ASPECTS OF PRIVILEGES AND IMMUNITIES OF DIPLOMATIC AGENTS IN INTERNATIONAL LAW:

\title{
THEORY AND PRACTICE
}

Monograph

B\&M Publishing

San Francisco, California, USA 
THE SPECIFIC ASPECTS OF PRIVILEGES AND IMMUNITIES OF DIPLOMATIC AGENTS IN INTERNATIONAL LAW:

THEORY AND PRACTICE

Monograph

B\&M Publishing

San Francisco, California, USA 


\section{B\&M Publishing}

Dvornyicsenko, N. 2017, The specific aspects of privileges and immunities of diplomatic agents in international law: theory and practice: monograph, B\&M Publishing, San Francisco, California. 384 pp.

The present monograph is a comparative study of the concept of diplomatic privileges and immunities, with regard to the legal literature and the corresponding international legislation, extended to writings of legal scholars, representatives of both continental and common law. The relation of diplomatic agents to privileges and immunities, accorded to them, remains one of the most problematic matters of diplomacy law. In this way, addressing the aspects of the investigated topic, including examination of the current state of affairs, regarding diplomatic privileges and immunities, revising the sources of diplomacy law, essential relevant concepts, instruments of enforcement of diplomatic privileges and immunities, along with means of protection of diplomats, was supported by a wide-ranging spectrum of bibliography.

The materials examined, include theoretical writings, historical resources, also various legal sources, official documents, academic journals and relevant academic publications, policy statements, scholarly articles, website materials, internet publications, media releases, originally issued in English, Hungarian, Russian, Ukrainian, Belorussian, French and German.

Consideration of issues, related to the subject of diplomatic privileges and immunities, has both theoretical and practical significance. The suggestions and results, obtained in the course of research, could be used in the further improvement of the various issues and problems, concerning personal privileges and immunities of diplomatic agents. The present study may be of interest for subsequent researchers in the field of diplomacy, as well as for current diplomatic servants. Successively, the monograph is assigned to students and university professors, postgraduates, faculty of advanced professional training, researchers, legal practitioners, career diplomats and other specialists and members of the state apparatus, as well as to all readers, interested in in questions of diplomacy law.

Copyright (C) 2017

by Natalia Dvornyicsenko

All rights reserved.

Published by B\&M Publishing.

San Francisco, California
ISBN-10:1-941655-51-3

ISBN-13:978-1-941655-51-1

DOI: http://doi.org/10.15350/267m 
To my beloved parents with profound gratitude 


\section{TABLE OF CONTENTS}

INTRODUCTION

I. THE CONCEPTUAL CLARIFICATION OF THE NOTION OF THE DIPLOMATIC AGENT ..... 11

I. 1. The basic concepts and terms of diplomacy, with regard to diplomatic privileges and immunities..

I. 2. The challenging métier of the diplomatic agent ........................................................... 17

II. SOURCES AND SUBJECTS OF DIPLOMACY LAW, WITH REGARD TO DIPLOMATIC

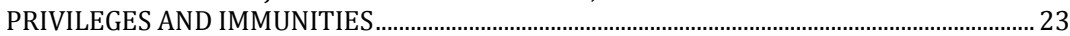

II. 1. Formal sources of diplomacy law, originating from international law..................... 23

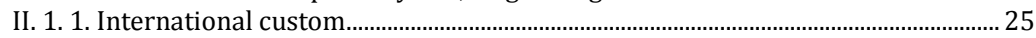

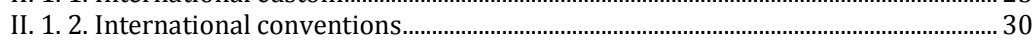

II. 2. Supplementary sources of diplomacy law, originating from judicial decisions and

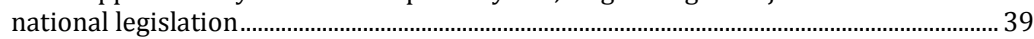

II. 2. 1. Judicial decisions at international level..................................................................... 39

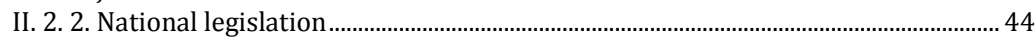

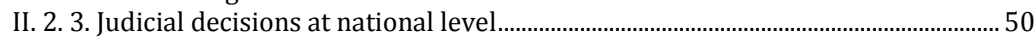

III. THEORETICAL BASIS OF THE INSTITUTION OF DIPLOMATIC PRIVILEGES AND

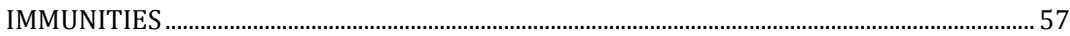

III. 1. The evolution of the institution of diplomatic privileges and immunities............. 57

III. 2. The conceptional clarification of the notion of diplomatic privileges and

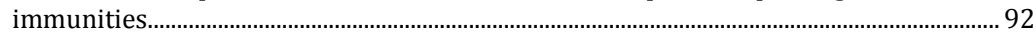

III. 3. The commencement and the termination of diplomatic privileges and

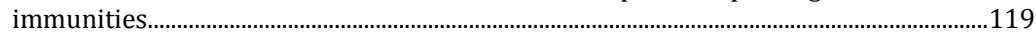

III. 3. 1. The theoretical and practical aspects of the commencement of diplomatic

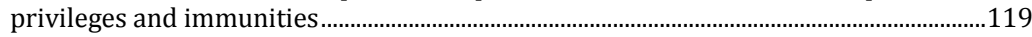

III. 3. 2. The theoretical and practical aspects of the termination of diplomatic

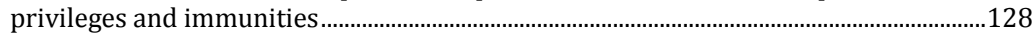

III. 3. 3. Diplomatic relations with authorities in exile .....................................................134

III. 4. The factors of reciprocity and non-discrimination, with regard to diplomatic

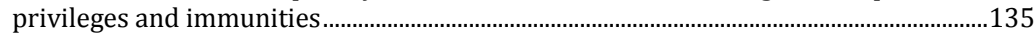

III. 4. 1. The conceptual clarification of the notion of reciprocity ……..............................135

III. 4. 2. The practical examples of application of the principle of reciprocity ................141

III. 4. 3. Secondary, honorary and ceremonial privileges, provided to diplomatic

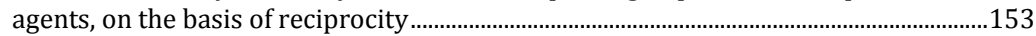

III. 5. Responses and countermeasures of states, with regard to diplomatic privileges

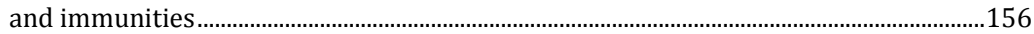

IV. PERSONAL INVIOLABILITY OF THE DIPLOMATIC AGENT: CATEGORIES OF

DIPLOMATIC IMMUNITY ......................................................................................................... 172

IV. 1. Immunity from civil and administrative jurisdiction..............................................172

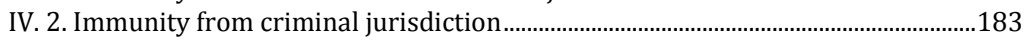

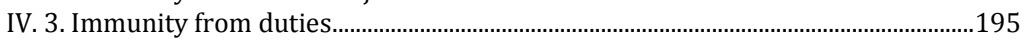

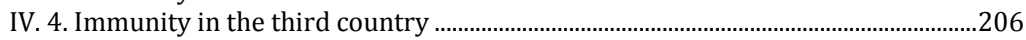

V. SPECIAL MATTERS OF DIPLOMATIC PRIVILEGES AND IMMUNITIES ................................210

V. 1. Abuse of diplomatic privileges and immunities .........................................................210

V.1.1. The measures and proposals, to address abuse of diplomatic privileges and

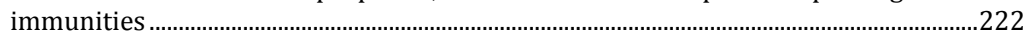

V. 2. Diplomatic intercourse and freedom of diplomatic communication ........................225

V. 2. 1. The challenges of diplomatic communication in modern times .........................232 
V. 2. 2. Diplomatic information and intelligence

V. 2. 2. 1. Examples of diplomatic involvement into intelligence activities from the sixteenth century until the end of the World War II

V. 2. 1. 2. Examples of diplomatic involvement into intelligence activities from the period of the Cold War until the contemporary period.....................................................253

V. 3. Freedom of diplomatic movement ..................................................................................26

V. 4. International protection of the diplomatic agent .........................................................269

V. 4. 1. Examples of violation of diplomatic immunity by the receiving states from the sixteenth century until the period of the Cold War.............................................................2. V. 4. 2. Examples of violation of diplomatic immunity by the receiving states from the period of the Cold War until the contemporary period....................................................2276

V. 4. 3. Measures of special protection of diplomatic agents, adopted by states in

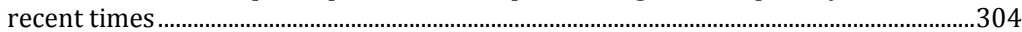

CONCLUSIONS

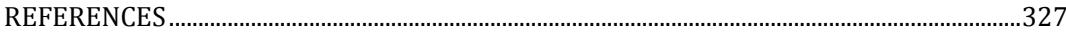

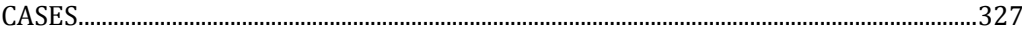

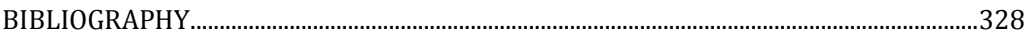

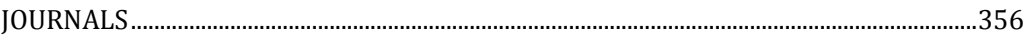

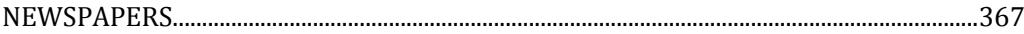

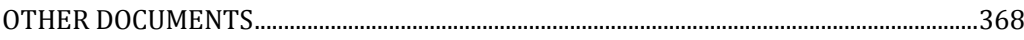

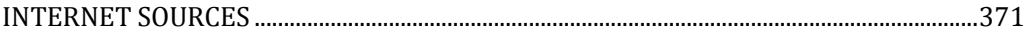




\section{B\&M Publishing}

Dvornyicsenko, N. 2017, The specific aspects of privileges and immunities of diplomatic agents in international law: theory and practice: monograph, B\&M Publishing, San Francisco, California. 384 pp.

PQN 500

ISBN-10:1-941655-51-3

ISBN-13:978-1-941655-51-1 